\title{
Isolation of 12 microsatellite markers following a pyrosequencing procedure and cross-priming in two invasive cryptic species, Alexandrium catenella (group IV) and A. tamarense (group III) (Dinophyceae)
}

\author{
Martin Laporte ${ }^{\mathrm{a}, \mathrm{b}}$, Zhaojun Shao ${ }^{\mathrm{a}}$, Patrick Berrebi ${ }^{\mathrm{a}}$, Mohamed Laabir ${ }^{\mathrm{c}}$, Eric Abadie ${ }^{\mathrm{d}}$, Nicolas Faivre ${ }^{\mathrm{c}}$, \\ Fabien Rieuvilleneuve ${ }^{c}$, Estelle Masseret ${ }^{\mathrm{c}, ~ *}$
}

\author{
a Institut des Sciences de l'Evolution de Montpellier, UMR 5554 UM2-CNRS-IRD, Université Montpellier II, \\ CC065, Place E. Bataillon, 34095 Montpellier, Cedex 5, France \\ ${ }^{\mathrm{b}}$ Département de Biologie, IBIS (Institut de Biologie Intégrative et des Systèmes), Université Laval, Québec G1V \\ 0A6, Canada \\ ${ }^{\mathrm{C}}$ Ecologie des Systèmes Marins Côtiers, UMR 5119 UM2-CNRS-IRD-Ifremer-UM1, Université Montpellier II, CC \\ 093, 34095 Montpellier Cedex 5, France \\ ${ }^{\mathrm{d}}$ Laboratoire Environnement Ressources Languedoc-Roussillon Ifremer, B.P. 171, 34203 Sète, France \\ *: Corresponding author : Estelle Masseret, tel.: +33 467144762 ; \\ email address : estelle.masseret@univ-montp2.fr
}

\begin{abstract}
:
Alexandrium catenella (group IV) and Alexandrium tamarense (group III) (Dinophyceae) are two cryptic invasive phytoplankton species belonging to the $A$. tamarense species complex. Their worldwide spread is favored by the human activities, transportation and climate change. In order to describe their diversity in the Mediterranean Sea and understand their settlements and maintenances in this area, new microsatellite markers were developed based on Thau lagoon (France) samples of $A$. catenella and $A$. tamarense strains. In this study twelve new microsatellite markers are proposed. Five of these microsatellite markers show amplifications on $A$. tamarense and ten on $A$. catenella. Three of these 12 microsatellite markers allowed amplifications on both cryptic species. Finally, the haplotypic diversity ranged from 0.000 to 0.791 and 0.000 to 0.942 for $A$. catenella and $A$. tamarense respectively.
\end{abstract}

\section{Highlights}

Alexandrium catenella (IV) and Alexandrium tamarense (III) are two cryptic invasive species. Twelve new microsatellite markers were developed based of French strains. Five markers showed amplifications on $A$. tamarense and ten on $A$. catenella. Three allowed amplifications on both cryptic species. - These new markers will allow a better understanding of both species' biogeography.

Keywords: Invasive species ; Phytoplankton ; Alexandrium ; Dinophyceae ; Microsatellite markers ; Biogeography 


\section{Introduction}

Proliferation phenomena of harmful phytoplankton are known as Harmful Algal Blooms (HABs). The worldwide spread of the HAB events is worrisome. Forty percent of harmful species are toxic and cause different syndromes associated with neurological or gastric disorders in humans after consumption of contaminated aquatic organisms (Zingone and Enevoldsen, 2000). Anthropogenic pressures (environmental/climate changes, shellfish transplantation, shipping) have broken the ecological barriers which had driven isolation and evolution of original areas (Smayda, 2007). Health and socioeconomic impacts of $\mathrm{HABs}$ prove dramatic effects on commercially exploitable resources (Hoagland and Scatasta, 2006). Since 1970, five times more areas are affected by HAB type paralytic shellfish poisoning (Glibert et al., 2005). The cosmopolite Alexandrium genus (Dinophyceae) regroups 31 toxic and non toxic species (Anderson et al., 2012). The two cryptic species Alexandrium catenella and A. tamarense belonging to the $A$. tamarense complex, spreading on the world coastal waters were classified as invasive species by Molnar et al. (2008). A. catenella (group VI-Temperate Asian clade) and A. tamarense (group III-Western European clade) have been recorded in the Mediterranean Sea coastal waters of Spain, France, Italy, Tunisia and Algeria (Lilly et al., 2002-2007; Frehi et al., 2007; Turki et al., 2007; Penna et al., 2008; Genovesi et al., 2011). Microsatellite markers have already been developed from A. tamarense strains (I-North American clade) and from A. catenella (IV-Temperate Asian clade) isolated from Scottish and Japanese strains (Nagai et al., 2004; Alpermann et al., 2006; Nagai et al., 2006; Nishitani et al., 2007). However, these markers did not work on A. tamarense (III) (Nagai et al., 2007) or appeared to be poorly polymorphic inside the French A. catenella (IV) population (Masseret et al., 2009).

The goal of this study is to develop new highly polymorphic microsatellite markers from Thau lagoon strains in order to describe the genetic diversity within Thau lagoon populations and among the Mediterranean populations in present and upcoming studies. This will help the understanding of the successful settlements and maintenances of these two planktonic invasive species under local environmental selective pressures and widely in the Mediterranean Sea. Thus, we describe here the development of twelve 
microsatellite markers and their cross-species application on both A. catenella and $A$. tamarense.

\section{Methods}

Two monoclonal strains isolated in 2007 from each A. catenella and A. tamarense species of Thau lagoon have been used to extract total genomic DNA following standard phenol-chloroform protocol (Sambrook et al., 1989; for strain isolation refer to Genovesi et al., 2011). The total genomic DNA was then sent to Genoscreen private company (Lille, France) to produce a coupling multiplex microsatellite enrichment isolation with the 454 GS-FLX Titanium pyrosequencing platforms, using the method described in Malaussa et al. (2011). From these microsatellite markers, the most promising were selected for their high repetitions and their absence of compound repeat to test their PCR amplification effectiveness.

In order to test the selected microsatellite markers, a total of 50 individuals of the A. tamarense species complex from the Thau lagoon (Mediterranean coast, France) were isolated: 26 individuals of $A$. catenella in autumn 2007 and 24 individuals of $A$. tamarense in spring 2007. Cultures were grown in enriched natural sea water (Harrison et al., 1980) at $20^{\circ} \mathrm{C}$, on a $12 \mathrm{~h}: 12 \mathrm{~h}$ light:dark cycle, using a photon flux density of 100 $\mu \mathrm{mol} \mathrm{m} \mathrm{m}^{-2} \mathrm{~s}^{-1}$. Total genomic DNA was extracted from the 50 individuals following standard phenol-chloroform protocol (Sambrook et al., 1989).

PCR amplifications were performed on an Eppendorf Mastercycler ${ }^{\circledR}$ in a reaction mixture $(10 \mu \mathrm{l})$ containing $20 \mathrm{ng}$ of DNA, $2.5 \mathrm{mM} / \mu \mathrm{l}$ of $\mathrm{MgCl}_{2}, 2 \mu \mathrm{l}$ of $5 \mathrm{X}$ buffer (Promega $^{\mathrm{TM}}$ ), $0.5 \mathrm{mM} / \mu 1$ of each new primer, $0.2 \mathrm{mM} / \mu \mathrm{l}$ for each dNTPs, $0.25 \mathrm{U}$ of Taq (Promega $^{\mathrm{TM}}$ ) and ultra-pure water quality. The primer cycling conditions were as follows: $10 \mathrm{~min}$ at $95^{\circ} \mathrm{C}, 39$ cycles of $30 \mathrm{sec}$ at $95^{\circ} \mathrm{C}, 30 \mathrm{sec}$ at primer specific annealing (see Table 1), $30 \mathrm{sec}$ at $72{ }^{\circ} \mathrm{C}$ and a final elongation of $5 \mathrm{~min}$ at $72{ }^{\circ} \mathrm{C}$. Pre-tests on selected microsatellite markers were produced to visualize allelic variation with non labelled primers on a new generation submarine electrophoresis system (ORIGINS by Elchrom $\left.^{\mathrm{TM}}\right)$, using E1600 gels to ensure high resolution on large ranged marker size (100 to $300 \mathrm{bp}$ ) on 8 individuals (4 A. catenella and 4 A. tamarense). Microsatellite markers 
that show allelic variation at least between species were then amplified again using primers labelled with FAM or CY5 followed by a migration on a denaturing $8 \%$ acrylamide gel on all 50 individuals. The gels were scanned on a FMBIO ${ }^{\circledR}$ fluorescent imaging system (HITACHI) and scored using GeneMapper® v4.0 (Applied Biosystems). The haplotypic diversity and the number of alleles were calculated respectively with FSTAT software v1.2 (Goudet, 1995) and CONVERT software v1.31 (Glaubitz, 2004).

\section{Results}

Two libraries of 1179 microsatellite markers for A. catenella and 1325 for A. tamarense were obtained from 454 GS-FLX Titanium pyrosequencing. From these libraries, 48 microsatellite markers ( 26 from A. catenella and 22 from A.tamarense) were selected according to their high repetitions and their absence of compound repeat. Of the 48 microsatellite markers checked from each library, 18 from A. catenella and 18 from $A$. tamarense libraries were rejected for unsuccessful PCR amplifications, scoring problems or lack of allelic variation. Of the twelve microsatellite markers remaining, five showed successful amplification for A. tamarense (R2M3-Atam05, R2M3-Atam09, R2M3Atam15, R2M3-Atam16 and R2M3-Acat22) and ten for A. catenella (R2M3-Atam05, R2M3-Atam09, R4M8-Acat02, R4M8-Acat05, R4M8-Acat09, R4M8-Acat19, R4M8Acat20, R4M8-Acat21, R4M8-Acat22 and R4M8-Acat 23). The characteristics of the twelve microsatellite markers selected ( 8 from A. catenella and 4 from A. tamarense libraries) are given in Table 1 . The haplotypic diversity ranged from 0.000 to 0.791 and 0.000 to 0.942 for A. catenella and A. tamarense respectively.

Three microsatellite markers worked on both species (R2M3-Atam05, R2M3Atam09 and R4M8-Acat22). However, R4M8-Acat22 showed difficulties in genotyping due to non-target bands in A. catenella electrophoregram (21 of 26). Furthermore, only R4M8-Acat09 showed no variation inside both Alexandrium species. Excluding this potential intra-species monomorphic loci, a total of 11 new microsatellite markers were evidenced to be polymorphic and applicable for at least one of the two species analysed in this study.

\section{Discussion}


As observed recently in other studies (Laporte et al., 2012; Froufe et al., 2013), second-generation sequencing of microsatellite-enriched libraries is useful to develop new microsatellite markers in non-model organisms in a shorter time and at relatively low expense compared with traditional methods. The new microsatellite markers developed in this study will be particularly important in order to understand the settlement and maintenance of two non-model invasive species in the Mediterranean Sea. Invasive species are recognized as one of the major causes of biodiversity loss in addition to changes in ecosystem functioning and services (Millennium Ecosystem Assessment, 2005). HAB events involve approximately $2 \%$ of known marine species of which most (75\%, 45-60 taxa) are Dinophyceae (Smayda, 1997). Alexandrium genus is among the most studied owing to the severe toxic events and because it exhibits enhanced fitness parameters in new colonized habitats (Jauzein et al., 2008; Anderson et al., 2012; Hadjadji et al., 2012). Microsatellite markers, commonly used as tools to describe population genetics of macroorganisms (Jarne and Lagoda, 1996) are now considered tools of choice for describing microorganisms' ecology and evolution (Pettay and LaJeunesse, 2013). Therefore, developing microsatellite markers to describe this toxic and invasive genus with the most precision as possible should be a priority.

At this point, population genetics studies performed across different geographic scales have highlighted a complex intraspecific diversity within the Alexandrium genus (Nagai et al., 2007; Masseret et al., 2009; Erdner et al., 2011; Casabianca et al., 2012; Richlen et al., 2012). However, the microsatellite markers presently available show lack of success in describing genetic diversity within the A. catenella (IV) population from Thau lagoon (Masseret et al., 2009) and does not amplify in A. tamarense (III). The new microsatellite markers developed in this study would help us explore (i) genetic diversity linked to reproduction modes (vegetative and asexual reproduction) and local selection processes, and (ii) population structure within both species` populations at different scales, in our local context, in the Mediterranean area and elsewhere. It is of interest to know if these new microsatellite markers can amplify other strains of each of the two considered species. Cross-priming has been successfully tested on a wider range of $A$. catenella (IV) strains isolated from sediments of Algeria and Tunisia (unpublished data). Concerning A. tamarense (III), no large scale experimentation has yet been performed. 
However, three microsatellite markers showed cross-priming between both species tested in this study and should therefore amplify on other strains of A.tamarense. Furthermore, cross-priming often works inside the A. tamarense complex. For example, microsatellite markers developed on A. tamarense amplify correctly for A. fundyense strains (Erdner et al., 2011) and several markers developed from Japanese strains of A. catenella (IV) (Nagai et al., 2006) show amplification on French strains despite low polymorphisms (Masseret et al., 2009). This addition of new highly polymorphic microsatellite markers to those already available should also increase the precision of different populations genetic statistics, which will lead to a better understanding of genetic diversity and population structure of all A. catenella and A. tamarense around the world.

\section{Acknowledgements}

We thank A. Kusler for English correction and the Fonds Québécois de la Recherche sur la Nature et les Technologies (FQRNT) for providing ML post-graduate fellowship. This work was supported by grants from the French National Programme Ecosphère Continentale et Côtière - EC2CO and from the Fondation pour la Recherche sur la Biodiversité - INVALEX project (AAPIN-2009-036). We thank the anonymous reviewer who contributed to improve this manuscript.

\section{References}

Alpermann T.J., John U.E., Medlin L.K., Edwards K.J., Hayes P.K., Evans K.M., 2006. Six new microsatellite markers for the toxic marine dinoflagellate Alexandrium tamarense. Molecular Ecolology Notes 6, 1057-1059.

Anderson D.M., Alpermann T.J., Cembella A.D., Collos Y., Masseret E., Montresor M., 2012. The globally distributed genus Alexandrium: Multifaceted roles in marine ecosystems and impacts on human health. Harmful Algae 14, 10-35.

Casabianca S., Penna A., Pecchioli E., Jordi A., Basterretxea G., Vernesi C., 2012. Population genetic structure and connectivity of the harmful dinoflagellate Alexandrium minutum in the Mediterranean Sea. Proceeding of the Royal Society B 279, 129-138. 
Erdner D.L., Richlen M., McCauley L.A.R, Anderson D.M., 2011. Intrapopulation diversity and dynamics of a widespread bloom of the toxic dinoflagellate Alexandrium fundyense. PLoS One 6: e22965, doi:10.1371/journal.pone.0022965.

Frehi H., Couté A., Mascarell G., Perrette-Gallet C., Ayada M., Kara M.H., 2007. Dinoflagellés toxiques et/ou responsables de blooms dans la baie d'Annaba (Algérie). Compte Rendus Biologie 330, 615-628.

Froufe E., Sobral C., Teixeira A., Lopes A., Sousa R., Varandas S., Lopes-Lima M., 2013. Development and multiplexing of microsatellite loci for the near threatened freshwater mussel Potomida littoralis (Cuvier, 1798) using 454 sequencing. Aquatic Conservation: Marine and Freshwater Ecosystems 23, 619-623.

Genovesi B., Shin-Grzebyk M.-S., Grzebyk D., Laabir M., Gagnaire P.-A., Vaquer A., Pastoureaud A., Lasserre B., Collos Y., Berrebi P., Masseret E., 2011. Assessment of cryptic species diversity within blooms and cyst bank of the Alexandrium tamarense complex (Dinophyceae) in a Mediterranean lagoon facilitated by semimultiplex PCR. Journal of Plankton Research. 33, 405-414.

Glaubitz J.C., 2004. CONVERT: a user friendly program to reformat diploid genotypic data for commonly used population genetic software packages. Molecular Ecolology Notes 4, 309-310.

Glibert P., Anderson D., Gentien P., Granéli E., Sellner K., 2005. The Global, Complex Phenomena of Harmful Algal Blooms. Oceanography 18,136-47.

Goudet J., 1995. FSTAT (Version 1.2): a computer program to calculate F statistics. Journal of Heredity 86, 485-486

Hadjadji I., Masseret E., Plisson B., Laabir M., Cecchi P., Collos Y., 2012. Clonal variation in physiological parameters of Alexandrium tamarense: implications for biological invasions and maintenance. Cahiers de Biology Marine 53, 357-363.

Harrison P.J., Waters R.E., Taylor F.J.R., 1980. A broad spectrum artificial seawatermedium for coastal and open ocean phytoplankton. Journal of Phycology $16,28-35$.

Hoagland P., Scatasta S., 2006. The economic effects of harmful algal blooms. in Ecological Studies 189: Ecology of Harmful Algae (E. Graneli and J.T. Turner, eds.). Springer-Verlag, Berlin. 
Jarne P., Lagoda P.J.L., 1996. Microsatellites, from molecules to populations and back. Trends in Ecology and Evolution 11, 424-429.

Jauzein C., Loureiro S., Garcés E., Collos Y., 2008. Interactions between ammonium and urea uptake by five strains of Alexandrium catenella (Dinophyceae) in culture. Aquatic Microbial Ecology 53, 271-280

Laporte M., Magnan P., Justy F., Tougard C., Berrebi P., 2012. Isolation of ten microsatellite markers using pyrosequencing procedure and cross-priming in the Salaria genus. Conservation Genetics Ressources 4, 151-154.

Lilly E., Kulis D., Gentien P., Anderson D., 2002. Paralytic shellfish poisoning toxins in France linked to a human-introduced strain of Alexandrium catenella from the western Pacific: evidence from DNA and toxin analysis. Journal of Plankton Research 24, 443-52.

Lilly E.L., Halanych K.M., Anderson D.M., 2007. Species boundaries and global biogeography of the Alexandrium tamarense complex (Dinophyceae). Journal of Phycology 43, 1329-1338.

Malaussa T., Gilles A., Meglécz E., Blanquart H., Duthoy S., Costedoat C., Dubut V., Pech N., Castagnone-Sereno P., Délye C., Feau N., Frey P., Gauthier P., Guillemaud T., Hazard L., Le Corre V., Lung-Escarmant B., Malé P.J.G., Ferreira S., Martin J.F., 2011. High-throughput microsatellite isolation through 454 GSFLX titanium pyrosequencing of enriched DNA libraries. Molecular Ecology Resources 11, 638-644

Masseret E., Grzebyk D., Nagai S., Genovesi B., Lasserre B., Laabir M., Collos Y., Vaquer A., Berrebi P., 2009. Unexpected genetic diversity among and within populations of the toxic dinoflagellate Alexandrium catenella as revealed by nuclear microsatellite markers. Applied and Environmental Microbiology 75, 2037-45.

Millennium Ecosystem Assessment., 2005. Ecosystems and human well-being, Synthesis reports, Island Press. 
Molnar J., Gamboa R., Revenga C., Spalding M., 2008. Assessing the global threat of invasive species to marine biodiversity. Frontiers in Ecology in the Environment 6, 485-92.

Nagai S., Lian C., Hamaguchi M., Matsuyama Y., Itakura S., Hogetsu T., 2004. Development of microsatellite markers in the toxic dinoflagellate Alexandrium tamarense (Dinophyceae). Molecular Ecology Notes 4, 83-85.

Nagai S., Sekino M., Matsuyama Y., Itakura S., 2006. Development of microsatellite markers in the toxic dinoflagellate Alexandrium catenella (Dinophyceae). Molecular Ecology Notes 6, 120-122.

Nagai S., Lian C., Yamaguchi S, Hamaguchi M., Matsuyama Y., Itakura S., Shimada H., Kaga S., Yamauchi H., Sonda Y., Nishikawa T., Kim C.H., Hogetsu T., 2007. Microsatellite markers reveal population genetic structure of the toxic dinoflagellate Alexandrium tamarense (Dinophyceae) in Japanese coastal waters. Journal of Phycology 43, 43-54.

Nishitani G., Nagai S., Masseret E., Lian C., Yamaguchi S., Yasuda N., Itakura S., Grzebyk D., Berrebi P., Sekino M., 2007. Development of compound microsatellite markers in the toxic dinoflagellate Alexandrium catenella (Dinophyceae). Plankton and Benthos Research 2, 128-133.

Penna A., Fraga S., Maso M., Giacobbe M.G., Bravo I., Garcés E., Vila M., Bertozzini E., Andreoni F., Luglie A., Vernesi C., 2008. Phylogenetic relationships among the Mediterranean Alexandrium (Dinophyceae) species based on sequences of 5.8S gene and internal transcript spacers of the rRNA operon. European Journal of Phycology 43, 163-178.

Pettay D.T., LaJeunesse T.C., 2013. Long-Range Dispersal and High-Latitude Environments Influence the Population Structure of a "Stress-Tolerant" Dinoflagellate Endosymbiont. PLoS ONE 8: e79208. doi:10.1371/journal.pone.0079208.

Richlen M.L., Erdner D.L., McCauley L.A.R., Libera K., Anderson D.M., 2012. Extensive genetic diversity and rapid population differentiation during blooms of Alexandrium fundyense (Dinophyceae) in an isolated salt pond on Cape Cod, MA, USA. Ecology and Evolution doi:10.1002/ece3.373 
Sambrook J., Fritsch E.F., Maniatis T., 1989. Molecular cloning: a laboratory manual, 2nd ed. Cold Spring Harbor Laboratory Press, Cold Spring Harbor, NY.

Smayda T.J., 1997. Harmful algal blooms: Their ecophysiology and general relevance to phytoplankton blooms in the sea. Limnology and Oceanography 425: 1137-1153.

Smayda T.J., 2007. Reflections on the ballast water dispersal-harmful algal bloom paradigm. Harmful Algae 6, 601-622.

Turki S., Balti N., Ben Janet H., 2007. First bloom of dinoflagellate Alexandrium catenella in Bizerte lagoon (northern Tunisia). Harmful Algae News 35, 7-9.

Zingone A., Enevoldsen H.O., 2000. The diversity of harmful algal blooms: a challenge for science and management. Ocean and Coastal Management 43, 725-748. 
Table 1

Primer pairs for amplification of twelve microsatellite regions for two cryptic species of A. tamarense complex (24 A. tamarense (III) and 26 A. catenella (IV) strains) isolated from Thau lagoon (France). Ta = Annealing temperature; NA = not applicable.

\begin{tabular}{|c|c|c|c|c|c|c|c|c|c|}
\hline Locus & $\begin{array}{c}\text { Repeat } \\
\text { motif }\end{array}$ & Primer sequence & $\begin{array}{c}\mathbf{T}_{\mathbf{a}} \\
\left({ }^{\circ} \mathbf{C}\right)\end{array}$ & Species & $\begin{array}{c}\text { Number of } \\
\text { non- } \\
\text { amplifying } \\
\text { samples }\end{array}$ & $\begin{array}{l}\text { Number } \\
\text { of alleles }\end{array}$ & $\begin{array}{l}\text { Size range } \\
\quad \text { (bp) }\end{array}$ & $\begin{array}{l}\text { Genetic } \\
\text { diversity } \\
\text { (He) }\end{array}$ & $\begin{array}{c}\text { Genbank } \\
\text { Accession } \\
\text { number }\end{array}$ \\
\hline $\begin{array}{l}\text { R2M3- } \\
\text { Atam05 }\end{array}$ & AAC (19) & $\begin{array}{l}\text { F: GTGCCTCTGCCTGTGCAT-Cy5 } \\
\text { R: CACAGACACCGCAATGTGTT }\end{array}$ & 60 & $\begin{array}{l}\text { A. catenella } \\
\text { A. tamarense }\end{array}$ & $\begin{array}{l}2 \\
5\end{array}$ & $\begin{array}{l}1 \\
1\end{array}$ & $\begin{array}{c}91 \\
277\end{array}$ & $\begin{array}{l}0.000 \\
0.000\end{array}$ & KF934393 \\
\hline $\begin{array}{l}\text { R2M3- } \\
\text { Atam09 }\end{array}$ & $\mathrm{AC}(18)$ & $\begin{array}{l}\text { F: TGCAACTGATACCCAAACCA-Cy5 } \\
\text { R: GTGTACACCACACTGTATATGGC }\end{array}$ & 55 & $\begin{array}{l}\text { A. catenella } \\
\text { A. tamarense }\end{array}$ & $\begin{array}{l}1 \\
1\end{array}$ & $\begin{array}{l}2 \\
9\end{array}$ & $\begin{array}{l}174-178 \\
110-160\end{array}$ & $\begin{array}{l}0.500 \\
0.763\end{array}$ & KF934394 \\
\hline $\begin{array}{l}\text { R2M3- } \\
\text { Atam15 }\end{array}$ & ACAG (16) & $\begin{array}{l}\text { F: CACTGCAAGGATCAGCTCAA-Cy5 } \\
\text { R: CCTGCATGTGCATGAGTGTA }\end{array}$ & 62 & $\begin{array}{l}\text { A. catenella } \\
\text { A. tamarense }\end{array}$ & $\begin{array}{c}26 \\
0\end{array}$ & $\begin{array}{c}N A \\
10\end{array}$ & $\begin{array}{c}N A \\
102-138\end{array}$ & $\begin{array}{c}N A \\
0.848\end{array}$ & KF934395 \\
\hline $\begin{array}{l}\text { R2M3- } \\
\text { Atam16 }\end{array}$ & $\mathrm{AC}(16)$ & $\begin{array}{l}\text { F: ATTGCCCACTTTGCCAAATA-FAM } \\
\text { R: CGTGTGAAGCGTGCATGTAT }\end{array}$ & 61 & $\begin{array}{l}\text { A. catenella } \\
\text { A. tamarense }\end{array}$ & $\begin{array}{c}26 \\
4\end{array}$ & $\begin{array}{c}N A \\
13\end{array}$ & $\begin{array}{c}N A \\
94-148\end{array}$ & $\begin{array}{c}N A \\
0.942\end{array}$ & KF934395 \\
\hline $\begin{array}{l}\text { R4M8- } \\
\text { Acat02 }\end{array}$ & AC (18) & $\begin{array}{l}\text { F: GTAATCCTGCAATCCGCAAT- } \\
\text { FAM } \\
\text { R: GTCATAACTGCCCATACGGC }\end{array}$ & 59 & $\begin{array}{l}\text { A. catenella } \\
\text { A. tamarense }\end{array}$ & $\begin{array}{c}0 \\
24\end{array}$ & $\begin{array}{c}7 \\
N A\end{array}$ & $\begin{array}{l}155-183 \\
\quad N A\end{array}$ & $\begin{array}{c}0.791 \\
N A\end{array}$ & KF934385 \\
\hline $\begin{array}{l}\text { R4M8- } \\
\text { Acat05 }\end{array}$ & $\mathrm{AC}(17)$ & $\begin{array}{l}\text { F: TTGGTGTCATCGAAGATTTCC- } \\
\text { Cy5 } \\
\text { R: TACAAGCACTGCGAACAACG }\end{array}$ & 59 & $\begin{array}{l}\text { A. catenella } \\
\text { A. tamarense }\end{array}$ & $\begin{array}{c}0 \\
24\end{array}$ & $\begin{array}{c}3 \\
N A\end{array}$ & $\begin{array}{c}115-123 \\
N A\end{array}$ & $\begin{array}{c}0.557 \\
N A\end{array}$ & KF934386 \\
\hline $\begin{array}{l}\text { R4M8- } \\
\text { Acat09 }\end{array}$ & ACAG (16) & $\begin{array}{l}\text { F: CTGGCGGTACAACAGACAT-FAM } \\
\text { R: CTGTCTGTATGTTTGATTGTTTGA }\end{array}$ & 59 & $\begin{array}{l}\text { A. catenella } \\
\text { A. tamarense }\end{array}$ & $\begin{array}{c}0 \\
24\end{array}$ & $\begin{array}{c}1 \\
N A\end{array}$ & $\begin{array}{l}116 \\
N A\end{array}$ & $\begin{array}{c}0.000 \\
N A\end{array}$ & KF934387 \\
\hline $\begin{array}{l}\text { R4M8- } \\
\text { Acat19 }\end{array}$ & AC (14) & $\begin{array}{l}\text { F: ATGCAAATGAACACAAGGCA- } \\
\text { FAM } \\
\text { R: TATTCAGCACGCTTATTGCG }\end{array}$ & 59 & $\begin{array}{l}\text { A. catenella } \\
\text { A. tamarense }\end{array}$ & $\begin{array}{c}0 \\
24\end{array}$ & $\begin{array}{c}3 \\
N A\end{array}$ & $\begin{array}{c}168-186 \\
N A\end{array}$ & $\begin{array}{c}0.280 \\
N A\end{array}$ & KF934388 \\
\hline $\begin{array}{l}\text { R4M8- } \\
\text { Acat20 }\end{array}$ & AC (14) & $\begin{array}{l}\text { F: } \\
\text { GACACATTGAAACAGTTTTCACAA- } \\
\text { FAM } \\
\text { R: GTGGGCTTGAGGTTGTGTTT }\end{array}$ & 59 & $\begin{array}{l}\text { A. catenella } \\
\text { A. tamarense }\end{array}$ & $\begin{array}{c}0 \\
24\end{array}$ & $\begin{array}{c}3 \\
N A\end{array}$ & $\begin{array}{c}164-184 \\
N A\end{array}$ & $\begin{array}{c}0.615 \\
N A\end{array}$ & KF934389 \\
\hline $\begin{array}{l}\text { R4M8- } \\
\text { Acat21 }\end{array}$ & $\mathrm{AC}(14)$ & $\begin{array}{l}\text { F: ACAGCTCAAAACGGCAGACT-Cy5 } \\
\text { R: GGTGTCTGCACTGCCTTGTA }\end{array}$ & 59 & $\begin{array}{l}\text { A. catenella } \\
\text { A. tamarense }\end{array}$ & $\begin{array}{c}0 \\
24\end{array}$ & $\begin{array}{c}4 \\
N A\end{array}$ & $\begin{array}{l}151-159 \\
\quad N A\end{array}$ & $\begin{array}{c}0.348 \\
N A\end{array}$ & KF934390 \\
\hline $\begin{array}{l}\text { R4M8- } \\
\text { Acat22 }\end{array}$ & $\begin{array}{l}\text { ACGAG } \\
\text { (14) }\end{array}$ & $\begin{array}{l}\text { F: CAGAATGTTCTGCGGTCATC-Cy5 } \\
\text { R: GAGAGCAGATCAGGGGCA }\end{array}$ & 59 & $\begin{array}{l}\text { A. catenella } \\
\text { A. tamarense }\end{array}$ & $\begin{array}{c}0^{*} \\
2\end{array}$ & $\begin{array}{l}2 \\
2\end{array}$ & $\begin{array}{l}137-139 \\
204-270\end{array}$ & $\begin{array}{l}0.600 \\
0.485\end{array}$ & KF934391 \\
\hline $\begin{array}{l}\text { R4M8- } \\
\text { Acat23 }\end{array}$ & $\mathrm{AC}(14)$ & $\begin{array}{l}\text { F: AATAGCGCCCGGTGTTAAGT-Cy5 } \\
\text { R: CGCACAACATACGGACACAT }\end{array}$ & 59 & $\begin{array}{l}\text { A. catenella } \\
\text { A. tamarense }\end{array}$ & $\begin{array}{c}0 \\
24\end{array}$ & $\begin{array}{c}4 \\
N A\end{array}$ & $\begin{array}{l}123-143 \\
N A\end{array}$ & $\begin{array}{c}0.665 \\
N A\end{array}$ & KF934392 \\
\hline
\end{tabular}

* While amplification is efficient, too much supplementary bands impeded a sure genotyping 